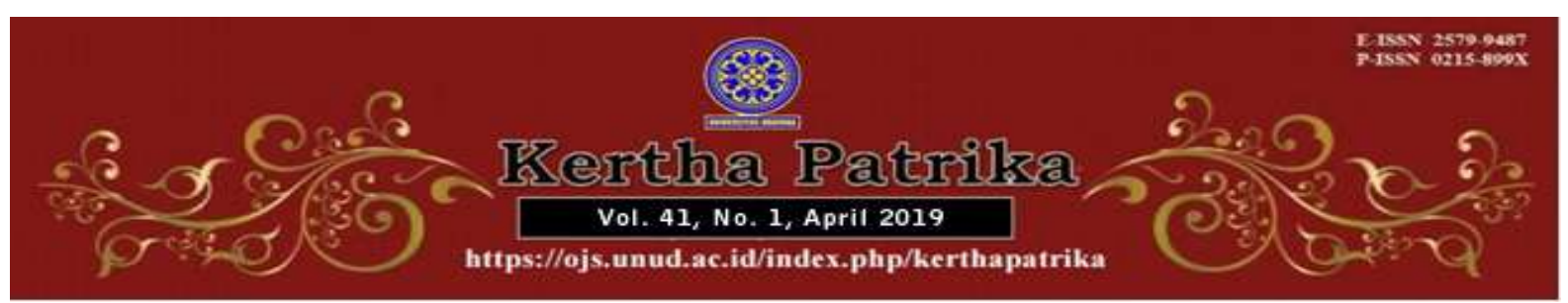

\title{
Penerapan Peraturan Kapolri Nomor 3 Tahun 2015 Tentang Pemolisian Masyarakat dalam Penegakan Hukum di Provinsi Gorontalo
}

\author{
Yoslan K. Koni ${ }^{1}$ \\ Fakultas Hukum Universitas Gorontalo, E-mail: yuslan.koni@gmail.com
}

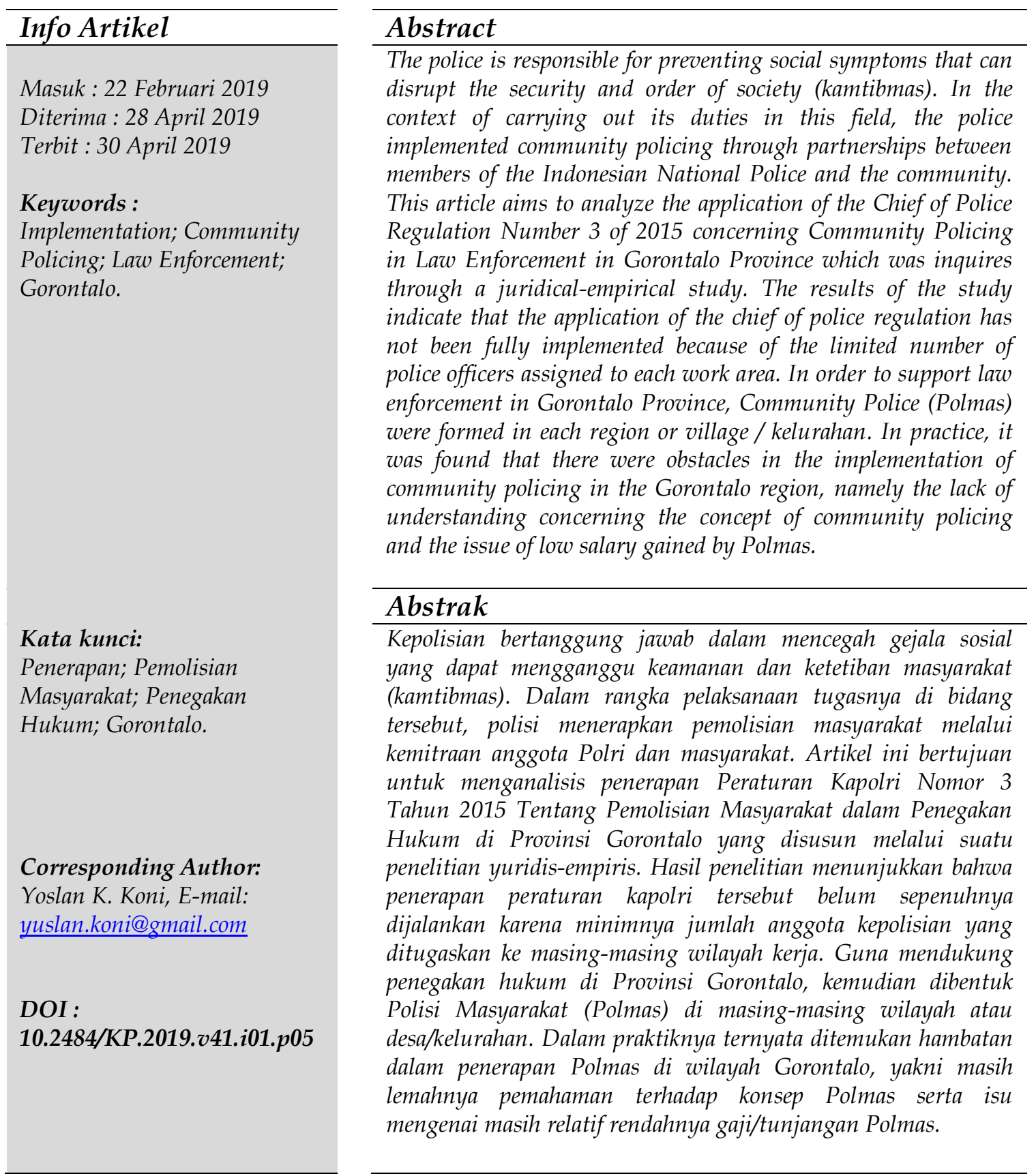




\section{Pendahuluan}

Kepolisian Negara Republik Indonesia (Polri) adalah alat negara yang mempunyai tugas pokok memelihara keamanan dan ketertiban masyarakat, melakukan penegakan hukum dan memberikan perlindungan, pengayoman, dan pelayanan kepada masyarakat, yang terdapat dalam Undang-Undang Nomor 2 Tahun 2002 tentang Kepolisian Negara Republik Indonesia. Polri bertanggung jawab di dalam mengupayakan, mencegah, dan mengeliminasi dari setiap gejala yang mungkin muncul dan dapat mengganggu keamanan dan ketertiban di masyarakat. Keamanan dan ketertiban masyarakat merupakan suatu situasi yang dibutuhkan dalam mendukung pelaksanaan pembangunan dan semua kegiatan masyarakat. ${ }^{1}$

Situasi Keamanandan ketertiban Masyarakat (Kamtibmas) sangat diharapkan oleh seluruh masyarakat untuk dapat diwujudkan, sehingga menimbulkan perasaan tentram dan damai bagi setiap masyarakat dan dapat meningkatkan motivasi dan semangat dalam bekerja, karena tidak ada rasa takut akibat kemungkinan adanya gangguan yang akan menimpa. Polri memiliki tugas yang cukup berat dalam pencegahan terjadinya pelanggaran dan kejahatan, pelayanan masyarakat dan melindungi serta menertibkan masyarakat. ${ }^{2}$

Polri sendiri dalam hal ini sudah mempersiapkan personil yang mewakili bidang pembinaan masyarakat. Intinya membangun kemitraan antara Polri dengan masyarakat sehingga terwujud rasa saling percaya, saling menghargai dan saling menghormati antara Polri dengan masyarakat. ${ }^{3}$ Polri dapat diterima dan didukung oleh masyarakat. Kegiatan Polri untuk mendorong, mengarahkan, dan menggerakkan masyarakat untuk berperan dalam Binkamtibmas (Pembina Keamanan dan Ketertiban Masyarakat) melalui bentuk Pamswakarsa dan penerapan model perpolisian masyarakat (Community Policing) antara lain dilakukan melalui penugasan anggota Polri menjadi Bhayangkara Pembina Kamtibmas (Bhabinkamtibmas) yang merujuk pada Surat Kepala Kepolisian Negara Republik Indonesia Nomor: B/3377/IX/2011/Baharkam tanggal 29 September 2011 tentang Penggelaran Bhabinkamtibmas di Desa/Kelurahan.

Bhayangkara Pembinaan Keamanan dan Ketertiban Masyarakat (Bhabinkamtibmas) adalah anggota Polri yang bertugas membina keamanan dan ketertiban masyarakat (kamtibmas). ${ }^{4}$ Tujuan yang ingin dicapai dalam kegiatan Bhabinkamtibmas adalah terwujudnya situasi kamtibmas yang mantap dan dinamis dalam rangka mengamankan dan menyukseskan pembangunan nasional. Sedangkan yang dimaksud dengan kamtibmas adalah suatu kondisi dinamis masyarakat yang ditandai oleh terjaminnya tertib dan tegaknya hukum serta terbinanya ketentraman yang mengandung kemampuan membina serta mengembangkan potensi dan kekuatan

1 Djanggih, H., \& Ahmad, K. (2017). The Effectiveness of Indonesian National Police Function on Banggai Regency Police Investigation (Investigation Case Study Year 2008-2016). Jurnal Dinamika Hukum, 17(2), 152-157. doi: http:/ / dx.doi.org/10.20884/1.jdh.2017.17.2.722, p. 153.

2 Sari, N. W. (2017). Peranan Bhayangkara Pembina Keamanan dan Ketertiban Masyarakat dalam Meningkatkan Pelayanan Keamanan Masyarakat di Polsek Sumoroto Kabupaten Ponorogo. Transformasi, 29(2). h.118.

3 Polri.(2012). Standar Operasional Prosedur Tentang Pelaksanaan Tugas Bhabinkamtibmasdi Desa/Kelurahan. Tanpa tempat terbit: POLRI,h.1.

4 Polri. (2014). Buku Pintar Bhabinkamtibmas. Tanpa tempat terbit: POLRI,h.3. 
masyarakat dalam menangkal, mencegah dan menanggulangi segala bentuk pelanggaran hukum dan bentuk-bentuk gangguan lainnya yang dapat meresahkan masyarakat, yang merupakan salah satu prasyarat terselenggaranya proses pembangunan nasional. ${ }^{5}$

Pedoman pelaksanaan tugas Bhabinkamtibmas yang utama adalah Buku Petunjuk Lapangan tentang Bhabinkamtibmas di Desa/Kelurahan No.Pol.: Bujuklap/17/VII/1997yang telah diubah dengan Keputusan Kapolri No.Pol.: Kep/8/XI/2009 tanggal 24 November 2009 tetang Perubahan Buku Petunjuk Lapangan Kapolri No.Pol.: Bujuklap/17/VII/1997, diubah lagi dengan Keputusan Kapolri No.Pol.: Kep/618/VII/2014 yang menjadi Buku Pintar Bhabinkamtibmas tahun 2014, Undang-undang No 2 tahun 2002 tentang Kepolisian Negara Republik Indonesia, dan Kebijakan dan Strategi Polri.

Bhabinkamtibmas merupakan program Markas Besar Polri untuk mendekatkan polisi dan membangun kemitraan dengan masyarakat. Bhabinkamtibmas mewujudkan misi melayani masyarakat dalam bentuk nyata agar peranan polisi dapat dirasakan langsung masyarakat desa dalam bentuk pendekatan pelayanan. ${ }^{6}$ Mendapatkan kepercayaan dari masyarakat merupakan hal yang sulit didapat, karena memerlukan proses terutama adanya komunikasi serta kontak sosial, waktu serta kemauan masingmasing anggota polisi. Masyarakat masih mengharapkan peningkatan peran dan tugas polisi sebagai pengayom, pelindung, dan pelayanan masyarakat serta sebagai penegak hukum yang bersih. ${ }^{7}$

Jumlah anggota Polisi di Indonesia bila dibandingkan dengan jumlah penduduk akan selalu tidak berimbang atau bahkan semakin ketinggalan, sehingga untuk mencapai rasio ideal (1:400) akan dibutuhkan waktu yang lama. Sementara, rasio polisi dan pendudukyang ideal pun tidak merupakan jaminan dapat terwujudnya Kamtibmas. Membangun kemitraan dengan masyarakat adalah strategi yang tepat untuk mengatasi kesenjangan ini. ${ }^{8}$

\section{Metode Penelitian}

Penelitian ini menggunakan metode penelitian yuridis-empiris. ${ }^{9}$ Pendekatan yuridis empiris, yaitu pendekatan masalah yang dilakukan dengan cara mengkaji peraturan perundang-undangan dan literatur serta bahan-bahan hukum, khususnya Peraturan Kapolri Nomor 3 Tahun 2015 Tentang Pemolisian Masyarakat dalam penerapannya di Provinsi Gorontalo.

5 Anonim. Peran Babinkabtibmas Dalam Peningkatan Pelayanan Masyarakat. Available fromhttps:// krisnaptik.com/2013/04/14/peran-babinkamtibmas-dalam-peningkatanpelayanan-masyarakat/.(Diakses 23 Desember 2018).

6 Rakhmat Ramadhan, (2017). Model Komunikasi Bhabinkamtibmas dalam Menjalin Kemitraan Kepada Masyarakat.Jurnal Ilmu KOMUNIKASI UHO, 2(1). h.1.

7 Rinawati, E.\& Mayarni.(2018). Pembinaan Keamanan dan keteriban Masyarakat (Kamtibmas) di Kelurahan Pangkalan Kerinci Barat.JOM FISIP, 5(2),1-13. h.3.

8 Anonim. Tentang Polmas. Available fromhttps://mwkusuma.files.wordpress.com/2009/10/perkap-no-07-2008-tentangpolmas.pdf.(Diakses 2 Nopember 2018).

9 Sulaiman, S. (2018). Paradigma dalam Penelitian Hukum. Kanun: Jurnal Ilmu Hukum. 20(2).doi: https://doi.org/10.24815/kanun.v20i2.10076., h. 267. 


\section{Hasil dan Pembahasan}

\subsection{Penerapan Peraturan Kapolri Nomor 3 Tahun 2015 Tentang Pemolisian Masyarakat Dalam Penegakan Hukum Di Provinsi Gorontalo}

Penerapan Peraturan Kapolri Nomor 3 Tahun 2015 tentang Pemolisian Masyarakat dalam penegakan hukum di Provinsi Gorontalo dilihat dari tugas pokok Kepolisian Republik Indonesia.Struktur kepolisian yang ditugaskan atau diturunkan ke masingmasing desa yang disebut sebagai Bhabhinkantibmas belum sepenuhnya terpenuhi sesuai dengan amanat peraturan kapolri karena masih kekurangan personil kepolisian sehingga satu orang anggota Bhabhinkantibmas dapat membina satu desa bahkan sampai lima desa dalam wilayah Kecamatan atau polsek masing-masing sehingga jika terjadi keributan atau permasalahan yang ada di desa maka anggota Bhabhinkantibmas yang ditugaskan kelelahan dalam mengatasi bahkan biasanya terlambat datang ke tempat permasalahan yang ada di desa binaannya.

Penegakan hukum merupakan usaha untuk mewujudkan ide-ide dan konsep-konsep hukum yang diharapakan rakyat menjadi kenyataan. Penegakan hukum merupakan suatu proses yang melibatkan banyak hal. ${ }^{10}$ Menurut Soerjono Soekanto, penegakan hukum adalah kegiatan menyerasikan hubungan nilai-nilai yang terjabarkan didalam kaidah-kaidah/pandangan nilai yang mantap dan mengejewantah dan sikap tindak sebagai rangkaian penjabaran nilai tahap akhir untuk menciptakan, memelihara dan mempertahankan kedamaian pergaulan hidup.

Penegakan hukum secara konkret adalah berlakunya hukum positif dalam praktik sebagaimana seharusnya patut dipatuhi. Oleh karena itu, memberikan keadilan dalam suatu perkara berarti memutuskan hukum in concreto dalam mempertahankan dan menjamin di taatinya hukum materiil dengan menggunakan cara prosedural yang ditetapkan oleh hukum formal. ${ }^{11}$ Penegakan hukum pada hakikatnya merupakan penegakan ide-ide atau konsep-konsep tentang keadilan, kebenaran, kemanfaatan sosial, dan sebagainya. Jadi, penegakan hukum merupakan usaha untuk mewujudkan ide dan konsep-konsep tadi menjadi kenyataan. ${ }^{12}$

Hakikatnya penegakan hukum mewujudkan nilai-nilai atau kaedah-kaedah yang memuat keadilan dan kebenaran, penegakan hukum bukan hanya menjadi tugas dari para penegak hukum yang sudah di kenal secara konvensional, tetapi menjadi tugas dari setiap orang. Meskipun demikian, dalam kaitannya dengan hukum publik pemerintahlah yang bertanggung jawab. ${ }^{13}$

Penegakan hukum dibedakan menjadi dua, yaitu: ${ }^{14}$

1. Ditinjau dari sudut subyeknya:

Dalam arti luas, proses penegakkan hukum melibatkan semua subjek hukum dalam setiap hubungan hukum. Siapa saja yang menjalankan aturan normative atau melakukan sesuatu atau tidak melakukan sesuatu dengan mendasarkan diri pada

10 Shant, D. (1988). Konsep Penegakan Hukum. Yogyakarta: Liberty,h. 32.

11 Ibid.h. 33.

12 Raharjo, A., \& Angkasa, A. (2011). Profesionalisme Polisi Dalam penegakan Hukum. Jurnal Dinamika Hukum, 11(3), 389-401. doi: http://dx.doi.org/10.20884/1.jdh.2011.11.3.167, h. 389.

13 Suseno, B. (2016). E-Polmas: Paradigma Baru Pemolisian Masyarakat Era Digital. Jurnal Keamanan Nasional, 2(1). h.102.

14 Shant, D. (1988). Op.cit.h. 34. 
norma aturan hukum yang berlaku, berarti dia menjalankan atau menegakkan aturan hukum.

Dalam arti sempit, penegakkan hukum hanya diartikan sebagai upaya aparatur penegakan hukum tertentu untuk menjamin dan memastikan bahwa suatu aturan hukum berjalan sebagaimana seharusnya.

2. Ditinjau dari sudut obyeknya, yaitu dari segi hukumnya:

Dalam arti luas, penegakkan hukum yang mencakup pada nilai-nilai keadilan yang di dalamnya terkandung bunyi aturan formal maupun nilai-nilai keadilan yang ada dalam bermasyarakat. Dalam arti sempit, penegakkan hukum itu hanya menyangkut penegakkan peraturan yang formal dan tertulis.

Teori Penegakan Hukum Penegakan hukum merupakan suatu usaha untuk mewujudkan ide-ide keadilan, kepastian hukum dan kemanfaatan sosial menjadi kenyataan. Jadi penegakan hukum pada hakikatnya adalah proses perwujudan ideide. Penegakan hukum adalah proses dilakukannya upaya tegaknya atau berfungsinya norma-norma hukum secara nyata sebagai pedoman pelaku dalam lalu lintas atau hubungan-hubungan hukum dalam kehidupan bermasyarakat dan bernegara. ${ }^{15}$

Penegakan hukum merupakan usaha untuk mewujudkan ide-ide dan konsepkonsep hukum yang diharapakan rakyat menjadi kenyataan. Penegakan hukum merupakan suatu proses yang melibatkan banyak hal. ${ }^{16}$

Joseph Goldstein membedakan penegakan hukum pidana menjadi 3 bagian yaitu:17

1. Total enforcement, yakni ruang lingkup penegakan hukum pidana sebagaimana yang dirumuskan oleh hukum pidana substantif (subtantive law of crime). Penegakan hukum pidana secara total ini tidak mungkin dilakukan sebab para penegak hukum dibatasi secara ketat oleh hukum acara pidana yang antara lain mencakup aturanaturan penangkapan, penahanan, penggeledahan, penyitaan dan pemeriksaan pendahuluan. Disamping itu mungkin terjadi hukum pidana substantif sendiri memberikan batasan-batasan. Misalnya dibutuhkan aduan terlebih dahulu sebagai syarat penuntutan pada delik-delik aduan (klacht delicten). Ruang lingkup yang dibatasi ini disebut sebagai area of no enforcement (area tanpa penegakan).

2. Full enforcement (penegakan penuh), setelah ruang lingkup penegakan hukum pidana yang bersifat total tersebut dikurangi area of no enforcement dalam penegakan hukum ini para penegak hukum diharapkan penegakan hukum secara maksimal.

3. Actual enforcement (penegakan yang sebenarnya), menurut Joseph Goldstein full enforcement ini dianggap not a realistic expectation (bukan harapan yang realitis), sebab adanya keterbatasan keterbatasan dalam bentuk waktu, personil, alat-alat investigasi, dana dan sebagainya, yang kesemuanya mengakibatkan keharusan dilakukannya discretion (kebijaksanaan) dan sisanya inilah yang disebut dengan actual enforcement (penegakan yang sebenarnya).

15 Suparmin, S. (2015). Peranan Polri dalam Penegakan Keadilan Masyarakat dalam Perspektif "Restorative Community Justice". Qistie Jurnal Ilmu Hukum, 8(1). h.6.

16 Shant, D. (1988). Loc.cit. h. 37.

17 Ibid. h. 39. 
Sebagai suatu proses yang bersifat sistemik, maka penegakan hukum pidana menampakkan diri sebagai penerapan hukum pidana criminal law application (aplikasi hukum pidana) yang melibatkan perbagai sub sistem struktural berupa aparat kepolisian, kejaksaan, pengadilan dan pemasyarakatan. Termasuk didalamnya tentu saja lembaga penasehat hukum. Dalam hal ini penerapan hukum haruslah dipandang dari 3 dimensi:

1. penerapan hukum dipandang sebagai sistem normatif (normative system) yaitu penerapan keseluruhan aturan hukum yang menggambarkan nilai-nilai sosial yang didukung oleh sanksi pidana.

2. penerapan hukum dipandang sebagai sistem administratif (administrative system) yang mencakup interaksi antara pelbagai aparatur penegak hukum yang merupakan sub sistem peradilan diatas.

penerapan hukum pidana merupakan sistem sosial (social system), dalam arti bahwa dalam mendefinisikan tindak pidana harus pula diperhitungkan pelbagai perspektif pemikiran yang ada dalam lapisan masyarakat.

\subsection{Hambatan Proses Penerapan Pemolisian Masyarakatdi Provinsi Gorontalo}

Faktor faktor yang mempengaruhi penegakan hukum menurut Soerjono Soekanto adalah: 18

1. Faktor Hukum

Praktik penyelenggaraan hukum di lapangan ada kalanya terjadi pertentangan antara kepastian hukum dan keadilan, hal ini disebabkan oleh konsepsi keadilan merupakan suatu rumusan yang bersifat abstrak, sedangkan kepastian hukum merupakan suatu prosedur yang telah ditentukan secara normatif.

Justru itu, suatu kebijakan atau tindakan yang tidak sepenuhnya berdasar hukum merupakan sesuatu yang dapat dibenarkan sepanjang kebijakan atau tindakan itu tidak bertentangan dengan hukum. Maka pada hakikatnya penyelenggaraan hukum bukan hanya mencakup law enforcement (penegakan hukum), namun juga peace maintenance (pemeliharaan perdamaian), karena penyelenggaraan hukum sesungguhnya merupakan proses penyerasian antara nilai kaedah dan pola perilaku nyata yang bertujuan untuk mencapai kedamaian.

2. Faktor Penegakan Hukum

Fungsi hukum, mentalitas atau kepribadian petugas penegak hukum memainkan peranan penting, kalau peraturan sudah baik, tetapi kualitas petugas kurang baik, ada masalah. Oleh karena itu, salah satu kunci keberhasilan dalam penegakan hukum adalah mentalitas atau kepribadian penegak hukum.

3. Faktor Sarana atau Fasilitas Pendukung

Faktor sarana atau fasilitas pendukung mencakup perangkat lunak dan perangkat keras, salah satu contoh perangkat lunak adalah pendidikan. Pendidikan yang diterima oleh Polisi dewasa ini cenderung pada hal-hal yang praktis konvensional, sehingga dalam banyak hal polisi mengalami hambatan di dalam tujuannya, diantaranya adalah pengetahuan tentang kejahatan computer, dalam tindak pidana khusus yang selama ini masih diberikan wewenang kepada jaksa, hal tersebut karena secara teknis yuridis polisi dianggap belum mampu dan belum

18 Soekanto.S. (2004). Faktor-Faktor Yang Mempengaruhi Penegeakan Hukum. Cetakan Kelima.Jakarta: Raja Grafindo Persada, h. 42. 
siap. Walaupun disadari pula bahwa tugas yang harus diemban oleh polisi begitu luas dan banyak.

4. Faktor Masyarakat

Penegak hukum berasal dari masyarakat dan bertujuan untuk mencapai kedamaian di dalam masyarakat. Setiap warga masyarakat atau kelompok sedikit banyaknya mempunyai kesadaran hukum, persoalan yang timbul adalah taraf kepatuhan hukum, yaitu kepatuhan hukum yang tinggi, sedang, atau kurang. Adanya derajat kepatuhan hukum masyarakat terhadap hukum, merupakan salah satu indikator berfungsinya hukum yang bersangkutan.

5. Faktor Kebudayaan

Berdasarkan konsep kebudayaan sehari-hari, orang begitu sering membicarakan soal kebudayaan. Kebudayaan menurut Soerjono Soekanto, mempunyai fungsi yang sangat besar bagi manusia dan masyarakat, yaitu mengatur agar manusia dapat mengerti bagaimana seharusnya bertindak, berbuat, dan menentukan sikapnya kalau mereka berhubungan dengan orang lain. Dengan demikian, kebudayaan adalah suatu garis pokok tentang perikelakuan yang menetapkan peraturan mengenai apa yang harus dilakukan, dan apa yang dilarang.

Penerapan Peraturan Kapolri Nomor 3 tahun 2015 tentang Pemolisian Masyarakat di Provinsi Gorontalo dalam penegakan hukum berpedoman pada prinsip-prinsip Polmas seperti yang tercantum pada Pasal 3 Peraturan kapolri Nomor 3 tahun 2015 tentang Polmas, yakni:

a. komunikasi intensif, yaitu komunikasi dua arah yang dilakukan secara terusmenerus antara pengemban Polmas dengan masyarakat/komunitas melalui pertemuan langsung maupun tidak langsung dalam rangka membahas masalah keamanan dan ketertiban;

b. kesetaraan, yaitu kedudukan yang sama antara pengemban Polmas dan masyarakat/komunitas, saling menghormati dan menghargai perbedaan pendapat;

c. kemitraan, yaitu kerja sama yang konstruktif antara pengemban Polmas dengan masyarakat/komunitas dalam rangka pemecahan masalah sosial, pencegahan/penanggulangan gangguan keamanan dan ketertiban;

d. transparansi, yaitu keterbukaan antara pengemban Polmas dengan masyarakat/komunitas serta pihak-pihak lain yang terkait dengan upaya menjamin rasa aman, tertib, dan tenteram agar dapat bersamasama memahami permasalahan, tidak saling curiga, dan dapat meningkatkan kepercayaan satu sama lain;

e. akutanbilitas, yaitu dapat dipertanggungjawabkan pelaksanaan Polmas sesuai dengan prosedur dan hukum yang berlaku dengan tolok ukur yang jelas, seimbang dan objektif; f. partisipasi, yaitu kesadaran Polri dan warga masyarakat untuk secara aktif ikut dalam berbagai kegiatan masyarakat/komunitas dalam upaya memelihara rasa aman dan tertib, memberi informasi, saran dan masukan, serta aktif dalam proses pengambilan keputusan guna memecahkan permasalahan Kamtibmas dan tidak main hakim sendiri;

f. hubungan personal, yaitu pendekatan Polri kepada komunitas yang lebih mengutamakan hubungan pribadi daripada hubungan formal/birokratis;

g. proaktif, yaitu aktif (tidak bersifat menunggu) memantau dan memecahkan masalah sosial sesuai dengan ketentuan peraturan perundang-undangan untuk 
mencegah terjadinya gangguan keamanan dan ketertiban serta peningkatan pelayanan kepolisian; dan

h. orientasi pada pemecahan masalah, yaitu petugas Polri bersama-sama dengan masyarakat/komunitas melakukan identifikasi dan menganalisis masalah, menetapkan prioritas dan respons terhadap sumber/akar masalah.

Dengan berpedoman pada Falsafah Polmas seperti yang tertuang di dalam Pasal 4 yaitu masyarakat bukan merupakan objek pembinaan, melainkan sebagai subjek dan mitra yang aktif dalam memelihara Kamtibmas di lingkungannya sesuai dengan hukum dan hak asasi manusia, penyelenggaraan keamanan tidak akan berhasil, apabila hanya dilakukan oleh Polri, melainkan harus bersama-sama dengan masyarakat dalam menangani permasalahan Kamtibmas, menitikberatkan pada upaya membangun kepercayaan masyarakat terhadap Polri.

Dalam Penerapan hukum khususnya oleh anggota Bhabinkantibmas di Provinsi Gorontalo dalam hal penegakan hukum ada beberapa faktor yang dilaksanakan dalam hal mencegah atau meminimalisir permasalahan-permasalan yang terjadi di provinsi Gorontalo, terutama di desa-desa yang menjadi sasaran bhabinkantimas. Sebelumnya telah dijelaskan terlebih dahulu kenapa harus ada Polmas, karena sebelum konsep Community Policing diluncurkan terutama di negara-negara maju, penyelenggaraan tugas-tugas kepolisian baik dalam pemeliharaan keamanan dan ketertiban maupun penegakan hukum, dilakukan secara konvensional. Polisi cenderung melihat dirinya semata-mata sebagai pemegang otoritas dan institusi kepolisian dipandang semata-mata sebagai alat negara sehingga pendekatan kekuasaan bahkan tindakan represif seringkali mewarnai pelaksanaan tugas dan wewenang kepolisian. Walaupun prinsip-prinsip "melayani dan melindungi" (to serve and to protect) ditekankan, pendekatan-pendekatan yang birokratis, sentralistik, serba sama/seragam mewarnai penyajian layanan kepolisian. Gaya perpolisian tersebut mendorong polisi untuk mendahulukan mandat dari pemerintah pusat dan mengabaikan 'persetujuan' masyarakat lokal yang dilayani. Selain itu polisi cenderung menumbuhkan sikap yang menampilkan dirinya sebagai sosok yang formal, dan ekslusif dari anggota masyarakat lainnya. Pada akhirnya semua itu berakibat pada memudarnya legitimasi kepolisian di mata publik pada satu sisi, serta semakin berkurangnya dukungan publik bagi pelaksanaan tugas kepolisian maupun buruknya citra polisi pada sisi lain.

Kondisi seperti diutarakan pada huruf a, juga terjadi di Indonesia, lebih-lebih ketika Polri dijadikan sebagai bagian integral Angkatan Bersenjata Republik Indonesia (ABRI) dan polisi merupakan prajurit ABRI yang dalam pelaksanaan tugasnya diwarnai sikap dan tindakan yang kaku bahkan militeristik yang tidak proporsional. Perpolisian semacam itu juga ditandai antara lain oleh pelaksanaan tugas kepolisian, utamanya penegakan hukum, yang bersifat otoriter, kaku, keras dan kurang peka terhadap kebutuhan rasa aman masyarakat. Di sisi lain pelaksanaan tugas kepolisian sehari-hari, lebih mengedepankan penegakan hukum utamanya untuk menanggulangi tindak kriminal. Berdasarkan TAP MPR Nomor II/MPR/1993 tentang Garis Besar Haluan Negara yang berkaitan dengan Sistem Keamanan dan Ketertiban Masyarakat Swakarsa, Polri dibebani tugas melakukan pembinaan Kamtibmas yang diperankan oleh Babinkamtibmas sebagai ujung tombak terdepan. Pendekatan demikian memposisikan masyarakat seakan-akan hanya sebagai obyek dan polisi sebagai subjek 
yang "serba lebih" sehingga dianggap figur yang mampu menangani dan menyelesaikan segenap permasalahan Kamtibmas yang dihadapi masyarakat.

Sejalan dengan pergeseran peradaban umat manusia secara universal ${ }^{19}$ terutama di negara-negara maju, masyarakat cenderung semakin 'jenuh' dengan cara-cara lembaga pemerintah yang birokratis, resmi, formal/kaku, general/seragam dan lain-lain dalam menyajikan layanan publik. Terdapat kecenderungan bahwa masyarakat lebih menginginkan pendekatan-pendekatan yang personal dan menekankan pemecahan masalah dari pada sekedar terpaku pada formalitas hukum yang kaku. Dalam bidang penegakan hukum terutama yang menyangkut pertikaian antar warga, penyelesaian dengan mekanisme informal dipandang lebih efektif dari pada proses sistem peradilan pidana formal yang acapkali kurang memberikan peranan yang berarti bagi korban dalam pengambilan keputusan pemecahan masalah yang dideritanya.

Kondisi sebagaimana diutarakan di atas mendorong diluncurkannya programprogram baru dalam penyelenggaraan tugas kepolisian terutama yang disebut Community Policing. Lambat laun, Community Policing tidak lagi hanya merupakan suatu program dan/atau strategi melainkan suatu falsafah yang menggeser paradigma konvensional menjadi suatu model perpolisian baru dalam masyarakat madani. Model ini pada hakekatnya menempatkan masyarakat bukan semata-mata sebagai obyek tetapi mitra kepolisian dan pemecahan masalah (pelanggaran hukum) lebih merupakan kepentingan dari pada sekedar proses penanganan yang formal/prosedural.

Dalam kehidupan bermasyarakat bangsa Indonesia nilai-nilai yang terkandung dalam konsep Community Policing pada hakekatnya bukan merupakan hal yang asing. Kebijakan Siskamswakarsa diangkat dari nilai-nilai sosio-kultural masyarakat Indonesia, yang lebih menjunjung nilai-nilai sosial dari pada individu. Pelaksanaan pengamanan lingkungan secara swakarsa pernah/masih efektif berjalan. Pada bagianbagian wilayah/etnik tertentu nilai-nilai kultural masih efektif (bisa diefektifkan) dalam pemecahan masalah sosial pada tingkat lokal. Nilai saling memaafkan dijunjung tinggi dalam masyarakat Indonesia yang religius. Pada zaman dahulu dikenal adanya "Hakim Perdamaian" desa. Kondisi itu semua merupakan modal awal yang dapat berperan sebagai faktor pendukung yang efektif dalam pengembangan Community Policing "ala" Indonesia, jika dikelola secara tepat sesuai ke-kini-an dan sejalan dengan upaya membangun masyarakat madani khususnya kepolisian "sipil" yang menekankan pada pendekatan kemanusiaan khususnya perlindungan hak-Hak Asasi Manusia dalam pelaksanaan tugas kepolisian. ${ }^{20}$

Sejak tahun 1970-an di Indonesia tugas-tugas kepolisian ditetapkan represif, preventif, dan pre-emtif. Tugas-tugas pre-emtif dilakukan melalui kegiatan-kegiatan fungsi Pembinaan Masyarakat (BINMAS) atau Bimbingan Masyarakat (BIMMAS). Unit Bimmas ada di berbagai tingkat organisasi Polri sebagai berikut: Asisten Bimmas/Direktur Bimmas/Karo Bimmas pada Mabes Polri; Asisten Bimmas/Kadit Bimmas/Karo Binamitra pada tingkat Polda; Sat Bimmas/Kabag Binamitra pada tingkat Polres; dan Kanit Bimmas pada Polsek dibantu oleh para Bhabinkamtibmas

19 Bakar, O. (2017). Pengaruh Globalisasi Terhadap Peradaban. Jurnal Peradaban, 1, h. 77.

20 Marwiyah, S. (2014).Model Pemolisian Masyarakat Sebagai Upaya Penanggulangan Pembalakan Hutan.Jurnal Yustisia, 3(1). h.64. 
yang berada pada organisasi Polri terakhir unit Bimmas Polsek telah dihapuskan dengan pertimbangan tertentu.

Tugas Pokok Bhabinkamtibmas di tingkat desa/Kelurahan sebagaimana diatur dalam Buku Petunjuk Lapangan No. Pol BUJUKLAP/17/VII/1997. yang ditanda tangani Kapolri tanggal 18 Juli 1997 adalah:

a. Membimbing masyarakat bagi terciptanya kondisi yang menguntungkan upayapenertiban dan penegakan hukum, upaya perlindungan dan pelayanan masyarakat di Desa/Kelurahan.

b. Sesuai dengan rumusan tugas pokoknya maka lingkup tugas Babinkamtibmas meliputi:

1) Membina kesadaran hukum masyarakat Desa/Kelurahan tentang:

a) Kedudukan, tugas wewenang, fungsi dan peranan polri.

b) Sangsi-sangsi pidana dan proses pemidanaan.

c) Hak dan kewajiban warga masyarakat dalam penegakan hukum.

2) Membina kesadaran Kamtibmas Desa/kelurahan tentang:

a) Masalah-masalah Kamtibmas.

b) Sebab-sebab timbulnya gangguan Kamtibmas.

c) Cara-cara penanggulangannya.

d) Cara-cara penyelenggaraan siskamling pemukiman.

c. Membina partisipasi masyarakat dalam rangka pembinaan Kamtibmas secara Swakarsa di Desa/Kelurahan.

d. Sebagai polisi di tengah-tengah masyarakat Babinkamtibmas juga melakukan tugas-tugas kepolisian umum dalam hal-hal tertentu sesuai dengan sikon setempat yaitu:

1) Mengumpulkan bahan keterangan.

2) Mengamankan kegiatan-kegiatan masyarakat.

3) Menerima laporan pengaduan masyarakat.

4) Memberi bantuan pengawalan, pencarian dan pertolongan kepada masyarakat.

5) Membina tertib lalu lintas.

6) Penanganan tingkat pertama kejahatan, pelanggaran atau kecelakaan di TKP.

7) Melaksanakan tugas-tugas dibidang pembangunan atau kegiatan kemasyarakat berdasarkan permintaan instansi yang berwenang dan masyarakat setempat.

Buku petunjuk tersebut telahada sejak kepemimpinan Polri sebelumnya, namun dalam praktek harus diakui bahwa realisasi di lapangan masih sangat jauh dari petunjuk yang terdapat dalam buku petunjuk tersebut. Setelah reformasi ${ }^{21}$ dimana kedudukan polri dipisahkan dari TNI/ABRImaka reformasipolri bergulir dengan cepat. Dengan bantuan berbagai negara donor dan lembaga-lembaga internasional maka Perpolisian

21 Setiabudhi, I. K. R., Artha, I. G., \& Putra, I. P. R. A. (2018). Urgensi Kewaspadaan Dini dalam Rangka Memperkuat Persatuan dan Kesatuan Bangsa. Jurnal Magister Hukum Udayana (Udayana Master Law Journal), 7(2),250-266. doi: https://doi.org/10.24843/JMHU.2018.v07.i02.p09, h. 251. 
Masyarakat yang merupakan terjemahan dari Community Policingmulai diterapkan di Indonesia. ${ }^{22}$

Praktek pembinaan mayarakat melalui program Babinkamtibmas di lingkungan Polri sebagai upaya pemecahan masalah di masyarakat merupakan hal yang baru bagi Polri dan termasuk di Amerika. Pada prosesnya, setelah melalui proses uji coba, dan pembentukan model yang dimotori oleh berbagai donor seperti: IOM, JIKA/Jepang, Asian Fopndatian, Pardnership dan UNHCR pada tanggal 13 Oktober 2005 dengan keputusan Kapolri No. Pol.: Skrp/737/X/2005 secara resmi Perpolisian Masyarakat menjadi kebijakan yang harus diterapkan oleh seluruh jajaran Polri.

Dari penjelasan di atas, maka strategi Polmas untuk mencapai penegakan hukum yang efektif dimasyarakat, khususnya di wilayah Provinsi Gorontalo yaitu dengan cara membangun kemitraan antara polri dan warga masyarakat yang mampu mengidentifikasi akar permasalahan, menganalisa, menetapkan prioritas tindakan, mengevaluasi efektifitas tindakan dalam rangka memelihara keamanan, ketertiban dan ketentraman masyarakat serta peningkatan kwalitas hidup masyarakat. Adapun sasaran strategi Polmas meliputi:

a. tumbuhnya kesadaran dan kepedulian masyarakat / komunitas terhadap potensi gangguan keamanan, ketertiban dan ketentraman di lingkungannya.

b. Meningkatkan kemampuan masyarakat bersama dengan polisi untuk mengidentifikasi akar permasalahan yang terjadi di lingkungannya, melakukan analisa dan memecahkan masalahnya.

c. Meningkatnya kemampuan masyarakat untuk mengatasi permasalahan yang ada bersama-sama dengan polisi dan dengan cara yang tidak melanggar hukum.

d. Meningkatnya kesadaran hukum masyarakat.

e. Meningkatnya parmas dalam menciptakan kamtibmas di lingkungannya masingmasing.

f. Menurunnya peristiwa yang mengganggu keamanan, ketertiban dan ketentraman masyarakat/komunitas.

Metode Polmas adalah melalui penyelenggaraan kemitraan antara Polri dengan warga masyarakat yang didasari prinsip kesetaraan guna membangun kepercayaan warga masyarakat terhadap Polri sehingga terwujud kebersamaan dalam rangka memahami masalah kamtibmas dan masalah sosial, menganalisis masalah, mengusulkan alternatif-alternatif solusi yang tepat dalam rangka menciptakan rasa aman, tentram dan keterlibatan (tidak hanya berdasarkan pada hukum pidana dan penangkapan), malakukan evaluasi serta evaluasi ulang terhadap aktifitas solusi yang dipilih karena Polmas mempunyai tujuan adalah terwujudnya kemitraan polisi dan masyarakat yang didasari kesadaran bersama dalam menanggulangi permasalahan yang dapat mengganggu keamanan dan ketertiban masyarakat guna menciptakan rasa aman, tertib dan tentram serta meningkatkan kualitas kehidupan masyarakat. ${ }^{23}$

22 Wahyurudhanto, A. W. A. (2018). Analisis Kemampuan Deteksi Dini oleh Bhabinkamtibmas dalam Implementasi Polmas sebagai Penguatan Program Satu Polisi Satu Desa. Jurnal Ilmu Kepolisian, 12(2). h.86.

23 Azhari, F. (2019). Polri: Dalam Fungsi Penegakan Ketertiban dan Dasar Kehidupan Masyarakat. Jurnal Hukum, 26(2). h.659. 
Upaya menanggulangi permasalahan yang dapat mengganggu keamanan, ketertiban dan ketentraman masyarakat yang mencakup rangkaian upaya pencegahan dengan melakukan identifikasi akar permasalahan, menganalisis, menetapkan perioritas tindakan, melakukan evaluasi dan evaluasi ulang atas efektifitas tindakan. ${ }^{24}$

Kemitraan polisi dan masyarakat meliputi mekanisme kemitraan yang mencakup keseluruhan proses managemen, mulai dari perencanaan, pengawasan, pengendalian, analisa dan evaluasi atas pelaksanaannya. Kemitraan tersebut merupakan proses yang berkelanjutan. ${ }^{25}$ Dalam rangka mewujudkan masyarakat yang aman, tertib dan tentram, warga masyarakat diberdayakan untuk ikut aktif menemukan, mengidentifikasi, menganalisis dan mencari jalan keluar bagi masalah-masalah yang mengganggu keamanan, ketertiban dan masalah sodial lainnya. Masalah yang dapat diatasi oleh masyarakat terbatas pada masalah yang ringan, tidak termasuk pelanggaran hukum yang serius.

Dengan berbagai upaya yang dilaksanakan oleh Polmas,Peraturan Kapolri Nomor 3 tahun 2015 benar-benar dirasakan oleh masyarakat baik tingkat Provinsi, Kota, Kabupaten, bahkan sampai pada desa-desa bisa merasakan hidup nyaman, tenteram tanpa ada gangguan dan ancaman manapun sehingga penegakan hukum dalam masyarakat bisa benar-benar tercapai baik dari sisi keadilan, kemanfaatan semua masyarakat dapat merasakanya.

Dalam praktiknya, ternyata ditemui hambatan dalam penerapan Polmas di wilayah Gorontalo. Ada 2 faktor yang menjadi hambatan, yakni (1) belum semua kepala satuan wilayah (Kasatwil) memahami konsep Polmas; dan (2) masih relatif rendahnya gaji/tunjangan Polmas.

\section{Kesimpulan}

Mendasari pembahasan sebelumnya, kesimpulan penelitian sebagai berikut: Pertama, penerapan Peraturan Kapolri Nomor 3 Tahun 2015 dalam menciptakan penegakan hukum di Provinsi Gorontalo belum sepenuhnya dijalankan karena masih banyak kekurangan anggota personil kepolisian yang ditugaskan ke masing-masing wilayah kerja. Guna mendukung penegakan hukum di Provinsi Gorontalo, kemudian dibentuk Polisi Masyarakat (Polmas) di masing-masing wilayah atau desa/kelurahan. Adapun peran Polisi Masyarakat (Polmas) yang ditugaskan di masing-masing wilayah atau desa/kelurahan dalam hal mendukung penegakan hukum di Provinsi Gorontalo adalah untuk menciptakan keamanan dan ketertiban masyarakat (Kamtibmas) melalui koordinasi dengan kepolisian sektor (Polsek) di masing-masing kabupaten/kota.Kedua, terdapat hambatan dalam penerapan pemolisian masyarakat di wilayah Gorontalo, yakni belum semua kepala satuan wilayah (Kasatwil) memahami konsep Polmas serta masih relatif rendahnya gaji/tunjangan Polmas.Penelitian ini hendak memberikan saran kepada Pemerintah Provinsi Gorontalo bersama pihak Kepolisian Daerah Gorontalo untuk memberikan sosialisasi mengenai keberadaan, tugas dan wewenang

24 Wulan, A. (2017). Meninjau Perspektif Polri tentang Pemolisian di Wilayah Negara Kepulauan Indonesia. Abad: Jurnal Sejarah, 1(2). h.62.

25 Humberto, M. (2012). POKDARKAMTIBMAS Pamulang sebagai Implementasi Kemitraan dalam Konteks Community Policing. Jurnal Kriminologi Indonesia, 7(1). h. 47. 
Polmas secara lebih optimal. Selain itu, diperlukan juga adanya peningkatan tunjangan bagi para anggota Polmas yang ditugaskan di masing-masing wilayah kabupaten/kota di Provinsi Gorontalo. Dengan demikian, Polmas dapat bekerja secara lebih efektif untuk mendukung proses penegakan hukum di wilayah Gorontalo.

\section{Ucapan terima Kasih (Acknowledgments)}

Ucapan terima kasih dan penghargaan kepada bapak Dr. Marten Bunga, SH, MH selaku Dekan Fakultas Hukum Universitas Gorontalo yang telah mendorong penulis sebagai Dosen di Fakultas Hukum Universitas Gorontalo untuk menyelesaikan karya tulis ilmiah ini dalam pemenuhan Tri Dharma Perguruan Tinggi di bidang penelitian.

\section{DAFTAR PUSTAKA}

\section{$\underline{\text { Buku }}$}

Polri.(2012). Standar Operasional Prosedur Tentang Pelaksanaan Tugas Bhabinkamtibmasdi Desa/Kelurahan. Tanpa tempat terbit: POLRI.

Polri. (2014). Buku Pintar Bhabinkamtibmas.Tanpa tempat terbit: POLRI.

Shant, D. (1988). Konsep Penegakan Hukum. Yogyakarta: Liberty.

Soekanto.S. (2004).Faktor-Faktor Yang Mempengaruhi Penegeakan Hukum. Cetakan Kelima. Jakarta: Raja Grafindo Persada.

\section{Jurnal}

Azhari, F. (2019). Polri: Dalam Fungsi Penegakan Ketertiban Dan Dasar Kehidupan Masyarakat. Jurnal Hukum, 26(2).

Bakar, O. (2017). Pengaruh Globalisasi Terhadap Peradaban. Jurnal Peradaban, 1.

Djanggih, H., \& Ahmad, K. (2017). The Effectiveness of Indonesian National Police Function on Banggai Regency Police Investigation (Investigation Case Study Year 2008-2016). Jurnal Dinamika Hukum,17(2), 152-157. doi: http://dx.doi.org/10.20884/1.jdh.2017.17.2.722

Humberto, M. (2012). POKDARKAMTIBMAS Pamulang sebagai Implementasi Kemitraan dalam Konteks Community Policing. Jurnal Kriminologi Indonesia, 7(1).

Raharjo, A., \& Angkasa, A. (2011). Profesionalisme Polisi Dalam penegakan Hukum. Jurnal Dinamika Hukum, 11(3), http://dx.doi.org/10.20884/1.jdh.2011.11.3.167 389-401

Rakhmat Ramadhan, (2017). Model Komunikasi Bhabinkamtibmas Dalam Menjalin Kemitraan Kepada Masyarakat, Jurnal Ilmu KOMUNIKASI UHO, 2(1).

Rinawati E \& Mayarni, (2018). Pembinaan Keamanan dan Ketertiban Masyarakat (Kamtibmas) di Kelurahan Pangkalan Kerinci Barat, JOM FISIP, 5(2), 1-13. 
Sari, N. W. (2017). Peranan Bhayangkara Pembina Keamanan dan Ketertiban Masyarakat dalam Meningkatkan Pelayanan Keamanan Masyarakat di Polsek Sumoroto Kabupaten Ponorogo. Transformasi, 29(2).

Setiabudhi, I. K. R., Artha, I. G., \& Putra, I. P. R. A. (2018). Urgensi Kewaspadaan Dini dalam Rangka Memperkuat Persatuan dan Kesatuan Bangsa. Jurnal Magister Hukum Udayana (Udayana Master Law Journal), 7(2), 250-266.doi: https://doi.org/10.24843/JMHU.2018.v07.i02.p09 250-266

Siti Marwiyah.(2014).Model Pemolisian Masyarakat Sebagai Upaya Penanggulangan Pembalakan Hutan.Jurnal Yustisia, 3(1).

Sulaiman, S. (2018). Paradigma dalam Penelitian Hukum. Kanun: Jurnal Ilmu Hukum. 20(2).doi: https://doi.org/10.24815/kanun.v20i2.10076 255-272

Suparmin, S. (2015). Peranan Polri dalam Penegakan Keadilan Masyarakat dalam Perspektif" Restorative Community Justice". Qistie Jurnal Ilmu Hukum, 8(1).

Suseno, B. (2016). E-Polmas: Paradigma Baru Pemolisian Masyarakat Era Digital. Jurnal Keamanan Nasional, 2(1).

Wahyurudhanto, A. W. A. (2018). Analisis Kemampuan Deteksi Dini oleh Bhabinkamtibmas dalam Implementasi Polmas sebagai Penguatan Program Satu Polisi Satu Desa. Jurnal Ilmu Kepolisian, 12(2).

Wulan, A. (2017). Meninjau Perspektif Polri tentang Pemolisian di Wilayah Negara Kepulauan Indonesia. Abad: Jurnal Sejarah, 1(2),61-71.

\section{Peraturan Perundang-undangan}

TAP MPR Nomor II/MPR/1993 tentang Garis Besar Haluan Negara.

Undang-Undang Nomor 8 Tahun 1981 Tentang Kitab Undang-Undang Hukum Acara Pidana, Lembaran Negara Republik Indonesia Tahun 1981 Nomor 76.

Undang-Undang Nomor 2 Tahun 2002 Tentang Kepolisian Negara Republik Indonesia, Lembaran Negara Republik Indonesia Tahun 2002 Nomor 2.

Peraturan Pemerintah pengganti UU No. 3 Thn. 2005 tentang perubahan atas UU Republik Indonesia No. 32 Thn. 2004 tentang Pemerintahan Daerah, Lembaran Negara Republik Indonesia Tahun 2005 Nomor 38.

Peraturan Kapolri Nomor 3 Tahun 2015 Tentang Pemolisian Masyarakat, Berita Negara Republik Indonesia Tahun 2015 Nomor 812.

Keputusan Presiden Republik Indonesia No. 70 Thn. 2002 tentang Organisasi dan Tata Kerja Kepolisian Negara Republik Indonesia.

Surat Kepala Kepolisian Negara Republik Indonesia Nomor: B/3377/IX/2011/Baharkam tanggal 29 September 2011 tentang Penggelaran Bhabinkamtibmas di Desa/Kelurahan.

Surat Keputusan No. Pol:SKEP/431/VII/2006 tentang pedoman pembinaan personil pengemban fungsi Perpolisian Masyarakat. 
Surat Keputusan Nomor Pol : SKEP/432/7/2006 tentang Panduan Pembentukan dan Operasionalisasi Perpolisian Masyarakat.

Buku Petunjuk Lapangan tentang Bhabinkamtibmas di Desa/Kelurahan No.Pol.: Bujuklap/17/VII/1997 yang telah diubah dengan Keputusan Kapolri No. Pol.: Kep/8/XI/2009 tanggal 24 November 2009 tetang Perubahan Buku Petunjuk Lapangan Kapolri No.Pol.: Bujuklap/17/VII/1997, diubah lagi dengan Keputusan Kapolri No.Pol.: Kep/618/VII/2014 yang menjadi Buku Pintar BHABINKAMTIBMAS tahun 2014.

\section{Internet}

Anonim

(2018).

Tentang

Polmas.

Retrieved

from

https://mwkusuma.files.wordpress.com/2009/10/perkap-no-07-2008-tentangpolmas.pdf, diakses 2 Nopember 2018.

Anonim. (2018). Peran Babinkabtibmas Dalam Peningkatan Pelayanan Masyarakat. Retrieved from https://krisnaptik.com/2013/04/14/peran-babinkamtibmasdalam-peningkatan-pelayanan-masyarakat/, diakses tangal 23 Desember 2018 